\title{
环境意识在市政工程的应用探讨
}

周忠斌

江苏龙典建设集团有限公司

DOI: 10.18686/bd.v1i11.1085

[摘 要] 环境意识是人类社会经济发展对环境的依赖以及环境对人类活动的限制作用, 认识或理解人与自然关系的理论、 思想、情感、意志等意识要素和观念形态的总和。环境意识是人们对环境和环境保护的一个认识水平、知程度; 是人们为保 护环境而不断调整自身经济活动及社会行为,协调人和环境、人和自然关系的实践活动的自觉性。

[关键词] 环境意识;市政工程;环境保护

\section{1 环境问题在市政工程建设中表现}

市政工程建设中, 很多的施工场所均在繁华主要街道 和市场附近, 施工周围的机关单位、居民住宅较多, 人口密度 稠, 车辆行驶较多。况且, 在施工现场往往会出现扬尘、施工 机械噪声大、施工水污染等有关环境问题十分普遍,这些环 境问题越来越引发人们的高度关切。我们都知道, 施工工地 扬尘、施工用水污染、大型机械噪声,包括固体废弃物等是 造成环境污染的主要因素。比如施工大气污染,这种污染主 要是指各类作业机械在施工当中将裸露在地表的沙土, 借 助自然风力而散发到空气中。道路扬尘、风蚀扬尘、拆除就 有设施扬尘基本均属于施工扬尘。道路扬尘在施工扬尘中 占最大比例, 主要体现为各类运输车辆在施工现场或者道 路上行驶而扬起的粉尘。如拆除旧式建筑、开挖地下管线、 清理和平整施工现场、装卸土方和材料、篮选和拌合建筑材 料、土方复原回填等这些都会产生施工扬尘。随着风力的运 动, 这些施工所产生的扬尘导致大气环境污染, 尤其是居民 居住较为集中的区域,受这种污染会引发环境污染纠纷。施 工噪声污染问题是长期引发环境纠纷的一个关键点, 噪声 污染主要产生于施工现场各种施工机械发出的噪声, 同时 还有建筑构件加工现场所产生的噪声源。这些噪声一旦影

听取不同人员的建议, 保证高效节水灌溉工程设计工作质 量。第三, 相关人员需要加强施工材料的采购工作, 严格按照 工程设计方案进行材料采购工作, 并对所采购的材料进行 质检, 保证施工材料质量。第四, 在高效节水灌溉工程施工前 期对, 需要组织施工人员对工程图纸进行分析, 然后做好技 术交底工作，对施工设计图纸中存在的问题及时进行改正， 保证高效节水灌溉工程设计工作质量。

\section{3 总结语}

总而言之, 在我国农业行业快速发展的今天, 对我国水 资源的使用效率逐渐增加, 在此种情况下, 相关人员要想在 灌溉过程中减少水资源浪费, 就需要创新灌溉方式,使用高 效节水的灌溉工程, 从而保证水资源使用效率, 做到水资源 节约,实现可持续发展战略目标。

\section{参考文献:}

响到人,那就会导致生活和健康质量的降低, 容易出现环境 污染纠纷。在市政环境方面, 施工水污染也是极为常见的环 境问题,这些是施工现场的生活污水排放形成的; 当然也有 施工功底的地面冲洗水、流失的浆料等。这些被污染的水一 旦深人到底下, 会渗透到附近的水井或者输水管线, 从而影 响到水质,增加了水体中的石油类及 $\mathrm{COD}$ 悬浮物等污染物 的浓度, 特别是一些河流长的水受到桥梁施工、施工固体废 弃物也会污染周围的水环境。市政建设中的建筑垃圾属于 固体废弃物, 这些废弃物量大。而且清运处理起来也破费周 折, 由于清运不及时, 只好随意堆放在施工周围, 其对水环境 污染也是不能轻视的环境问题。

\section{2 市政工程对环境的影响分析}

2.1 施工废弃物污染

市政工程施工涉及各个领域, 施工中难免会产生大量 废弃物,例如废弃的建筑材料、生活垃圾等, 若是没有对这些 施工废弃物进行妥善处理, 就在施工现场随意堆放, 就容易 产生恶臭味,进而对周边环境造成污染, 甚至也会对市政工 程施工的顺利进行产生一定的阻碍。此外, 施工废弃物还能 分为有毒废弃物和无毒废弃物, 无毒的废弃物必将容易处 理, 对环境污染的影响也较小, 而有毒的废弃物, 不仅处理起

[1]何月娥.浅析高效节水灌溉工程建设中存在的问题 与对策[J].科技与企业,2015,(6):92-92.

[2]李旭.高效节水灌溉工程建设中存在的问题与对策 [J].环球市场,2016,(35):160,162.

[3]张安安.高效节水灌溉工程建设中存在的问题与对 策[J].农民致富之友,2017(12):291.

[4]王虎甲.武威市凉州区发展高效节水灌溉工程存在 的问题与对策 [J].水资源开发与管理,2015,(4):63-64,31.

[5]阿米拉古丽.高效节水灌溉工程建设中存在的问题 与对策[J].建筑工程技术与设计,2016(9):1440-1440.

[6]高宏,鲍子云.宁夏高效节水灌溉发展存在的问题与 对策[J].中国水利,2017,(7):26-28.

[7] 吴艳春. 高效节水灌溉工程的优化设计要点探析 [J].南方农业,2015,9(15):148-149. 
来比较麻烦,对环境污染的影响也较大, 甚至很容易威胁人 民群众的生命健康。市政工程施工中的有毒废弃物有:废弃 化工材料、工业棉布、各种有毒清洗液等。

\section{2 大气污染}

市政工程施工中不可避免会产生大量的扬尘, 加上各 种施工机械设备的使用也会排放大量的废气，而由于空气 具有传播速度快、扩散范围大等特点, 一旦施工中产生扬 尘、排放废气, 就必定通过空气大范围的快速散播, 从而对施 工现场周边的空气质量造成严重污染。此外,施工中使用的 油漆、涂料等材料也会产生一定的废气。空气是无形无色 的,人类通过吸收空气中的氧气来存活,优质的空气中含氧 量极高,是人类生存的基础保障,而市政施工中产生的扬尘、 排放的废气将严重影响空气质量, 大大降低空气中的含氧 量,一旦大气被污染, 人类在吸收氧气的同时也被迫会吸收 这些废气、扬尘等有毒害气体物质,这将严重危害人类的生 命健康安全。

2.3 噪音污染

导致噪音污染出现的原因多种多样, 且噪音还有大小 和层次不同之分。而市政工程施工中产生噪音污染的主要 原因就是施工中使用的各种机械设备所发出的噪音, 主要 包括打桩机、切割机、挖掘机等机械设备。另外,市政工程中 的焊接施工也会产生噪音污染。一旦产生噪音污染, 不论噪 音大小或是什么层次, 都必定对施工现场周边环境造成严 重影响,甚至严重扰乱周边人民群众的日常生产生活。

2.4 水污染

市政工程施工中会使用大量的水,例如现场喷酒、现场 冲洗、生活用水等,若是这些水在使用后没有及时有效的进 行处理,那么就会产生大量污水。这些污水携带着浓烈的恶 臭味必定对周边环境产生影响,所以,如何处理这些污水是 市政施工企业必须重点解决的问题。

\section{3 加强环境意识,完善市政建设}

3.1 加强环保意识,实施施工全过程环境管理

3.1.1 施工中的噪声防治

应尽量采用低噪声设备和先进的施工技术, 如考虑选 用轻型震动设备,并及早淘汰性能落后、噪音超标的机械设 备; 合理安排施工时间,尽量将施工作业时间安排在白天,如 需夜间施工,必须提前办理夜间施工许可证, 在相关部门批 准后方可进行施工, 并加强机械保养,同时运用吸声、消声、 隔声等降噪技术,降低施工机械的噪声。

3.1.2 施工产生扬尘与废气排放的治理

施工所用的一些粉末材料不得直接露天堆放, 要加盖 蓬布或绿网, 以防大风造成的扬尘现象。作业时要轻装、轻 卸,并且应采用一些比较先进的现代化设备,来降低施工现 场的扬尘问题。运输道路要经常酒水养护, 运输水泥、土方 等粉质材料的车辆必须加盖篷布, 以降低道路扬尘。应加强 运输车辆及其他重型机械设备的养护工作, 使其始终处于
最佳工作状态, 以减少二氧化碳、二氧化硫和氮氧化物等污 染物的排放。

\subsection{3 施工产生废渣与废水的处理}

应对建筑垃圾进行分类处理，对其中的有用物质进行 回收循环利用,如砂、石类可作混凝土骨料, 碎砖头可作回填 料; 而对于没有回收价值的固体废弃物,则必须集中收集, 及 时清运,严禁将其乱放、乱卸或用于回填。应选择对外环境 影响较小的出土口、运输路线和运输时间; 减少回填土方的 堆放时间和堆放量;制定废渣的处理、处置方案,及时清运施 工弃土和渣土, 并建立登记制度,防止运输中途倾倒事件、撒 落事件的发生;剩余的料具、包装应及时回收和清退。在废 水治理方面,应泥浆水、摚拌站废水等施工废水进行妥善处 理,未经处理的不得排人城市污水管网或河流中造成污染; 施工现场生活污水和粪便等必须进行集中处理, 否则也不 可直接排人水体; 对现场存放油料的库房地面必须进行防 渗处理,油料使用时也要采取有效措施,防止油料因滴漏而 污染水体。

\section{2 加强制度建设,强化政府的环境管理}

政府可使用行政和经济等手段, 制约施工活动带来的 环境损害,强化政府的环境保护职能,加强环境保护立法工 作和制度建设,做好政府的环境管理。通过政府全面规划的 手段使项目建设和环境相协调, 在实施基础设施建设的同 时保护好环境。宏观上管理、引导教育,加强对具体项目的 监督工作, 极力构建既符合环保要求又适合经济发展的政 府环境管理模式。

\section{3 承包商的环境管理}

承包商严格遵守国家环境保护法律法规、增强环保意 识,做好施工期的环保工作。制定施工计划时,应对可能出现 的扬尘、噪声、水污染、固体废弃物等环境问题制定相应的 解决措施。施工中明确各类人员的环保责任, 项目经理定期 检查及时发现问题、解决问题,尽可能把项目对环境的负面 影响降到最低。

综上所述,在市政工程施工的过程中,环境保护是重要 的管理内容。因此,建立市政施工环境保护管理制度, 不仅有 利于提高施工作业的工作效率,减少事故的发生概率。还能 够加强施工人员的环境保护意识, 不断完善管理机构及相 关环境保护意识, 促进市政工程施工作业的高效有序的进 行,为建设美丽的城市做出最大的贡献。

\section{参考文献:}

[1]付超江.市政工程施工中的环境保护刍议[J].科技 与企业.2013,(21):114-115.

[2]朱涛.市政工程施工中的环境问题与保护措施[J]. 中华建设,2017,(03):128-129.

[3]郭龙.市政工程环境影响制度分析[J].住宅与房地 产,2016,(36):255. 